University of Nebraska - Lincoln

DigitalCommons@University of Nebraska - Lincoln

Faculty Papers and Publications in Animal

Science

Animal Science Department

2009

\title{
Effect of Essential Oils, Tylosin, and Monensin on Finishing Steer Performance, Carcass Characteristics, Liver Abscesses, Ruminal Fermentation, and Digestibility
}

\author{
N. F. Meyer \\ University of Nebraska-Lincoln \\ Galen E. Erickson \\ University of Nebraska-Lincoln, gerickson4@unl.edu \\ Terry J. Klopfenstein \\ University of Nebraska-Lincoln, tklopfenstein1@unl.edu \\ Matthew A. Greenquist \\ University of Nebraska-Lincoln, mgreenquist2@unl.edu \\ Matt K. Luebbe \\ University of Nebraska - Lincoln, mluebbe2@unl.edu \\ See next page for additional authors \\ Follow this and additional works at: https://digitalcommons.unl.edu/animalscifacpub \\ Part of the Animal Sciences Commons
}

Meyer, N. F.; Erickson, Galen E.; Klopfenstein, Terry J.; Greenquist, Matthew A.; Luebbe, Matt K.; Williams, P.; and Engstrom, M. A., "Effect of Essential Oils, Tylosin, and Monensin on Finishing Steer Performance, Carcass Characteristics, Liver Abscesses, Ruminal Fermentation, and Digestibility" (2009). Faculty Papers and Publications in Animal Science. 607.

https://digitalcommons.unl.edu/animalscifacpub/607

This Article is brought to you for free and open access by the Animal Science Department at DigitalCommons@University of Nebraska - Lincoln. It has been accepted for inclusion in Faculty Papers and Publications in Animal Science by an authorized administrator of DigitalCommons@University of Nebraska - Lincoln. 


\section{Authors}

N. F. Meyer, Galen E. Erickson, Terry J. Klopfenstein, Matthew A. Greenquist, Matt K. Luebbe, P. Williams, and M. A. Engstrom 


\title{
Effect of essential oils, tylosin, and monensin on finishing steer performance, carcass characteristics, liver abscesses, ruminal fermentation, and digestibility ${ }^{1}$
}

\author{
N. F. Meyer, ${ }^{*}$ G. E. Erickson, ${ }^{* 2}$ T. J. Klopfenstein, ${ }^{*}$ M. A. Greenquist, ${ }^{*}$ M. K. Luebbe,* \\ P. Williams, $\dagger$ and M. A. Engstrom $\dagger$ \\ *Department of Animal Science, University of Nebraska, Lincoln 68583; \\ and †DSM Nutritional Products Incorporated, Parsippany, NJ 07054
}

\begin{abstract}
A feedlot (Exp. 1) experiment was conducted to evaluate the effects of an essential oil mixture (EOM), experimental essential oil mixture (EXP), tylosin, and monensin (MON) on performance, carcass characteristics, and liver abscesses. A metabolism experiment (Exp. 2) was conducted to evaluate the effects of EOM, EXP, and MON on ruminal fermentation and digestibility in finishing steers. In Exp. 1, 468 yearling steers $(398 \pm 34 \mathrm{~kg}$ initial $\mathrm{BW})$ were used in 50 pens (10 pens/treatment) and received their respective dietary treatments for $115 \mathrm{~d}$. Five dietary treatments were compared in Exp. 1: 1) control, no additives $(\mathrm{CON}) ; 2)$ EOM, $1.0 \mathrm{~g} / \mathrm{steer}$ daily; 3) EXP, $1.0 \mathrm{~g} / \mathrm{steer}$ daily; 4) EOM, $1.0 \mathrm{~g} / \mathrm{steer}$ daily plus tylosin, $90 \mathrm{mg} /$ steer daily $(\mathrm{EOM}+\mathrm{T})$; and 5) monensin, $300 \mathrm{mg} / \mathrm{steer}$ daily plus tylosin, $90 \mathrm{mg} /$ steer daily $(\mathrm{MON}+\mathrm{T})$. Compared with $\mathrm{CON}$, steers fed $\mathrm{MON}+\mathrm{T}$ had decreased DMI $(P<0.01)$, and steers fed $\mathrm{EOM}+\mathrm{T}$ and $\mathrm{MON}+\mathrm{T}$ had improved G:F $(P \leq 0.02)$. Average daily gain was not different among treatments $(P>0.58)$. There was a trend $(P=0.09)$ for a treatment effect on 12th-rib
\end{abstract}

fat thickness, which resulted in a significant increase in calculated yield grade for the $\mathrm{EOM}+\mathrm{T}$ treatment. No other carcass characteristics were affected by treatment $(P \geq 0.10)$. Prevalence of total liver abscesses was reduced for steers fed tylosin compared with no tylosin $(P<0.05)$. In Exp. 2, 8 ruminally fistulated steers $(399 \pm 49 \mathrm{~kg}$ initial BW) were assigned randomly to 1 of 4 treatments in a replicated $4 \times 4$ Latin square designed experiment. Treatments were 1) CON, 2) EOM, 3) EXP, and 4) MON with feeding rates similar to Exp. 1. There were no differences in DMI, OM intake, and apparent total tract DM or OM digestibilities among treatments $(P>0.30)$. Feed intake patterns were similar among feed additive treatments $(P>0.13)$. Total VFA $(P=0.10)$ and acetate $(P=0.06)$ concentrations tended to be affected by treatment with EOM numerically greater than CON. Average ruminal $\mathrm{pH}$ ranged from 5.59 to 5.72 and did not differ among treatments. Addition of a EOM or monensin to a diet containing tylosin improves G:F, but little difference was observed in metabolism or digestibility.

Key words: cattle, essential oil, metabolism, monensin, performance, tylosin

(C2009 American Society of Animal Science. All rights reserved.

J. Anim. Sci. 2009. 87:2346-2354 doi:10.2527/jas.2008-1493

\section{INTRODUCTION}

Essential oils are naturally occurring, secondary plant metabolites that can be steam volatilized or extracted using organic solvents (Calsamiglia et al., 2007). A commercially available mixture of essential oils (CRINA Ruminant, DSM Nutritional Products, Parsippany, NJ) has shown promise in improving ruminal metabo-

\footnotetext{
${ }^{1}$ A contribution of the University of Nebraska Agricultural Research Division, supported in part by funds provided through the Hatch Act.

${ }^{2}$ Corresponding author: geericks@unlnotes.unl.edu

Received September 18, 2008.

Accepted March 10, 2009.
}

lism. Using in vitro procedures, improved ruminal responses such as methanogen inhibition and decreased ammonia production (McIntosh et al., 2003) have been observed, but in vitro responses have not translated into improved production characteristics in dairy cattle (Benchaar et al., 2006b, 2007).

Most of the data examining response to essential oils differ by species utilized, dietary treatment, and quantity of essential oil. No data are available evaluating essential oils for beef cattle fed high-concentrate diets to determine the effect on animal performance or metabolism (Benchaar et al., 2008). Monensin and tylosin are common feed additives for beef cattle finishing diets and differ in mode of action and ultimately animal response. Therefore, monensin and tylosin serve 
as unique comparisons with compounds tested for antimicrobial effects in beef finishing diets.

The objective of Exp. 1 was to determine the effect of feeding no feed additives, a commercially available essential oil mixture alone or in combination with tylosin, an experimental essential oil mixture alone, or monensin and tylosin on finishing cattle performance and carcass characteristics. Another objective was to compare feed intake behavior, rumen metabolism, and digestibility for cattle fed 1 of 2 essential oil mixtures alone compared with monensin or no feed additives.

\section{MATERIALS AND METHODS}

All procedures involving animal care and management were reviewed, approved, and are in accordance with the procedures outlined by the University of Nebraska-Lincoln Institutional Animal Care and Use Committee.

\section{Exp. 1}

Animals and Diets. Four hundred sixty-eight crossbred yearling steers (British and British $\times$ Continental) with an initial BW of $398 \pm 34 \mathrm{~kg}$ were used in a 115-d randomized complete-block design feeding experiment. Steers were received from a variety of sources (auction markets and ranch direct) from October 6, 2004 to October 22, 2004 as weaned calves. At arrival, steers were individually identified (panel tag, ear electronic button, and metal tag), vaccinated with Vista 5 and Once PMH (Intervet Inc., Millsboro, DE), Somubac (Pfizer Animal Health, New York, NY), and poured with Cydectin (Fort Dodge Animal Health, Fort Dodge, IA) parasiticide. Steers were revaccinated approximately 3 wk later with Pyramid 5 (Fort Dodge Animal Health), Vision 7 (Intervet Inc.), and Piliguard (Schering-Plough Corp., Kenilworth, NJ). From November 1, 2004 until April 15, 2005, steers grazed corn residue and were supplemented with wet corn gluten feed (Sweet Bran, Cargill Inc., Blair, NE). From April 16, 2005 until September 9, 2005, cattle grazed on native range in the Nebraska Sandhills (University of Nebraska, Barta Bros. Ranch, Rose, NE).

Steers were returned to the University of Nebraska research feedlot (Mead, NE) on September 9, 2005 where they were penned and fed a diet of $50 \%$ alfalfa hay, $25 \%$ wet corn gluten feed, and $25 \%$ rye distillers grains (DM basis) until study initiation. Five days before study initiation (September 19, 2005), steers were limit fed at $2 \%$ of $\mathrm{BW}$ daily to minimize variation in gastrointestinal fill (Stock et al., 1983). On d 0 and 1 , steers were individually weighed in a Silencer chute (Moly Manufacturing Inc., Lorraine, KS) suspended on load cells (Avery Weigh-Tronix, Fairmont, MN) and the mean BW was used to determine initial BW. Based on d-0 BW, steers were blocked by BW into 1 of 4 blocks: light $(352 \mathrm{~kg})$, mid-light $(388 \mathrm{~kg})$, mid-heavy $(422 \mathrm{~kg})$, and heavy $(474 \mathrm{~kg})$, stratified by BW within block, and assigned randomly to pens. Pens were assigned randomly to 1 of 5 treatments (10 pens/treatment). Cattle were housed in open dirt lot pens with 9 or 10 steers per pen (balanced by replication), 63 to $74 \mathrm{~m}^{2}$ of pen space, and 68 to $91 \mathrm{~cm}$ of linear bunk space per animal. Steers had ad libitum access to fresh clean water and their respective treatment diets. Steers were fed once daily at approximately $0830 \mathrm{~h}$ in concrete fence-line feedbunks with a Roto-Mix model 420 (RotoMix, Dodge City, KS) mixer/delivery box mounted on a single-axle feed truck.

On d 1, all steers were implanted with Revalor-S (Intervet Inc.) and received 1 of 5 feed additive treatments that were added to the basal diet (Table 1). Supplements were formulated to contain the different feed additive treatments with 1) control (CON, no feed additives); 2) essential oil mixture (EOM, targeted at $1.0 \mathrm{~g} /$ steer daily); 3) experimental essential oil mixture (EXP, targeted at $1.0 \mathrm{~g} /$ steer daily); 4) EOM plus tylosin $(\mathbf{E O M}+\mathbf{T}$, targeted at $1.0 \mathrm{~g} /$ steer daily and $90 \mathrm{mg} /$ steer daily, respectively); and 5) monensin plus tylosin (MON+T, targeted at $300 \mathrm{mg} /$ steer daily and $90 \mathrm{mg} /$ steer daily, respectively; monensin, Elanco Animal Health, Indianapolis, IN; tylosin, Elanco Animal Health). Dietary treatments containing EOM, EXP, $\mathrm{MON}$, and $\mathrm{T}$ contained these additives at concentrations of $90.0,90.0,26.4$, and $7.9 \mathrm{mg} / \mathrm{kg}$, respectively (DM basis). The EOM contained thymol, eugenol, vanillin, guaiacol, and limonene (Benchaar et al., 2007). The EXP contained guaiacol, linalool, and $\alpha$-pinene. Both mixtures are proprietary blends of essential oils on an organic carrier (DSM Nutritional Products Inc.). Diets were formulated to meet or exceed the NRC (1996) requirements for CP, calcium, phosphorus, and potassium. Steers were adapted to the finishing diet with a grain adaptation period that consisted of $3,3,4$, 7 , and $7 \mathrm{~d}$. During the grain adaptation period, highmoisture corn replaced alfalfa hay and was included at $0,28.5,38.5,48.5$, and $58.5 \%$; dry-rolled corn was included at $45,16.5,16.5,16.5$, and $16.5 \%$; and alfalfa was included at $45,45,35,25$, and $15 \%$ (DM basis) for each of the respective steps.

Carcass Data. On d 115, steers were fed $50 \%$ of DM offered the previous day. Pen weights (Digi-Star animal scale, Fort Atkinson, WI) were collected on the evening of d 115, and cattle were loaded and transported to a commercial abattoir (Greater Omaha Packing Co., Omaha, NE). After an overnight fast and water restriction, steers were slaughtered on d 116 with HCW and liver scores recorded at the time of slaughter. Liver abscesses were scored according to the Elanco scoring system: $\mathrm{A}-=1$ or 2 small abscesses or abscess scars; $\mathrm{A}=2$ to 4 small well-organized abscesses; and A+ $=1$ or more large or active abscesses with or without adhesions (Brink et al., 1990). After a 48-h chill, carcass data were collected that included 12th-rib fat thickness, LM area, KPH, and USDA marbling score. A calculated USDA yield grade (YG; Boggs and Merkel, 1993) was determined from the equation $[Y G=2.50$ 
$+(6.35 \times \mathrm{FT}, \mathrm{cm})-\left(2.06 \times \mathrm{LM}\right.$ area, $\left.\mathrm{cm}^{2}\right)+(0.2 \times$ $\mathrm{KPH}, \%)+(0.0017 \times \mathrm{HCW}, \mathrm{kg})]$. Values for final BW, ADG, and G:F were calculated using $\mathrm{HCW}$ divided by a common dressing percentage of $63 \%$ to minimize errors associated with gastrointestinal tract fill. However, live shrunk (4\%) final BW and dressing percentage are reported.

Sample Analysis. Weekly samples of ingredients were collected and composited by month for DM and nutrient content determination, and feed refusals were collected when determined necessary by a trained bunk reader. Ingredient samples and feed refusal DM was determined by drying at $60^{\circ} \mathrm{C}$ for $48 \mathrm{~h}$ in a forced-air oven. Crude protein was determined using a combustion $\mathrm{N}$ analyzer (Leco FP-528, Leco Corporation, St. Joseph, MI) using official AOAC (1995) method 990.03. Lipid content was determined using AOAC official method 920.39 for ether extraction (AOAC, 1995).

Statistical Analysis. Data were analyzed using the MIXED procedures (SAS Inst. Inc., Cary, NC) as a randomized complete block design, with pen as the experimental unit and $4 \mathrm{BW}$ blocks. Fixed effects included treatment and BW block. Treatment means were separated using an $F$-test protected LSD multiple comparison test. Treatment effects were declared significant at $P<0.05$, and trends were discussed at $P$ $\leq 0.10$.

\section{Exp. 2}

Animals and Sampling. Eight ruminally fistulated steers $(399 \pm 49 \mathrm{~kg}$ initial BW) were used in concurrent $4 \times 4$ Latin squares to determine digestibility and ruminal fermentation characteristics of diets with feed additives. Ruminal fistulation and postsurgical care followed procedures as outlined by Stock et al. (1991). Steers were maintained in a temperature-controlled room $\left(25^{\circ} \mathrm{C}\right)$ with ad libitum access to water and their diets. On d 1, all steers received 1 of 4 feed additive treatments that were added to the basal diet (Table 2). Supplements were formulated to contain different feed additive treatments with 1) CON (no feed additives), 2) EOM (targeted at $1.0 \mathrm{~g} /$ steer daily), 3) EXP (targeted at $1.0 \mathrm{~g} / \mathrm{steer}$ daily), and 4) MON (targeted at $300 \mathrm{mg} /$ steer daily). Dietary treatments containing EOM, EXP, and MON contained these additives at concentrations of $90.0,90.0$, and $28.2 \mathrm{mg} / \mathrm{kg}$, respectively (DM basis). Diets were formulated to meet or exceed the NRC (1996) requirements for CP, calcium, phosphorus, and potassium.

Four 28-d periods were utilized, with a 23-d adaptation period and a 5-d collection period. From d 1 to 23 , steers were individually fed in pens $(1.5 \times 2.4 \mathrm{~m})$ and on the evening of d 23 moved into tie stalls and tethered for the collection period. Steers remained in the tie stalls during the collection period (d 24 to 28) while continuous feed intake patterns and ruminal $\mathrm{pH}$ measurements were collected using a data acquisition program
Table 1. Composition of basal diet with differing feed additive treatments included in the supplement (Exp. 1)

\begin{tabular}{|c|c|}
\hline Item & $\%$ of dietary DM \\
\hline \multicolumn{2}{|l|}{ Ingredient composition } \\
\hline High-moisture corn & 66.0 \\
\hline Dry-rolled corn & 16.5 \\
\hline Alfalfa hay & 7.5 \\
\hline Molasses, liquid & 5.0 \\
\hline Dry meal supplement ${ }^{1}$ & 5.0 \\
\hline Fine ground corn ${ }^{2}$ & Variable \\
\hline Urea & 1.36 \\
\hline Limestone & 1.27 \\
\hline Salt & 0.30 \\
\hline Potassium chloride & 0.23 \\
\hline Tallow $^{3}$ & 0.13 \\
\hline Trace mineral premix ${ }^{4}$ & 0.050 \\
\hline Vitamin premix ${ }^{5}$ & 0.015 \\
\hline Essential oil mixture $^{6}$ & 0 or 0.009 \\
\hline Monensin premix ${ }^{7}$ & 0 or 0.015 \\
\hline Tylosin premix ${ }^{8}$ & 0 or 0.009 \\
\hline \multicolumn{2}{|l|}{ Nutrient composition $^{9}$} \\
\hline $\mathrm{CP}$ & 13.0 \\
\hline Calcium & 0.65 \\
\hline Phosphorus & 0.33 \\
\hline Potassium & 0.70 \\
\hline
\end{tabular}

${ }^{1}$ Supplement fed at $5 \%$ of diet DM with fine ground corn as a carrier and dietary treatments included within the supplement. All supplement ingredients are listed as \% of diet DM.

${ }^{2}$ Variable inclusion indicates that feed additives replaced part of fine ground corn.

${ }^{3}$ Tallow included in the supplement as a surfactant and dust controlling agent.

${ }^{4}$ Premix contained $6 \% \mathrm{Zn}, 5 \% \mathrm{Fe}, 4 \% \mathrm{Mn}, 2 \% \mathrm{Cu}, 0.2 \% \mathrm{I}, 0.05 \%$ Co.

${ }^{5}$ Premix contained 32,411 IU of vitamin A, 6,482 IU of vitamin D, $8.1 \mathrm{IU}$ of vitamin E per gram.

${ }^{6}$ Essential oil mixture (DSM Nutritional Products Inc., Parsippany, $\mathrm{NJ}$ ) formulated to provide 0 or $90 \mathrm{mg} / \mathrm{kg}$ and 0 or $1.0 \mathrm{~g} / \mathrm{steer}$ daily.

${ }^{7}$ Formulated to provide monensin (Elanco Animal Health, Indianapolis, IN) at 0 or $26.4 \mathrm{mg} / \mathrm{kg}$ of DM and 0 or $300 \mathrm{mg} /$ steer daily.

${ }^{8}$ Formulated to provide tylosin (Elanco Animal Health) at 0 or 7.9 $\mathrm{mg} / \mathrm{kg}$ of $\mathrm{DM}$ and 0 or $90 \mathrm{mg} /$ steer daily.

${ }^{9}$ Based on tabular values for individual feed ingredients (NRC, 1984).

as described by Cooper et al. (1999). Ruminal pH was measured continuously from d 24 to 28 with indwelling submersible probes (Sensorex, Garden Grove, CA) that recorded a $\mathrm{pH}$ measurement every $15 \mathrm{~s}$ and averaged $\mathrm{pH}$ readings for every minute (1,440 measurements/d). Feed intake was measured continuously with feed bunks suspended from load cells (Omega, Stamford, CT) that recorded a sample every $12 \mathrm{~s}$ and averaged data across every minute (1,440 measurements/d). A meal was defined as an eating bout where $\geq 1.0 \mathrm{~kg}$ of feed was consumed. Feed intake and $\mathrm{pH}$ measurements were interfaced with software (Labtech, Wilmington, MA) and recorded in Microsoft Excel (Microsoft Corporation, Redmond, WA) spreadsheets. Steers were fed once daily at $0730 \mathrm{~h}$, feed samples and refusals were collected, sub-sampled, and composited by period for analysis. Fecal output was determined using $\mathrm{Cr}_{2} \mathrm{O}_{3}$ as an indigestible marker during the collection period. Steers 
Table 2. Composition of basal diet with differing feed additive treatments included in the supplement (Exp. 2)

\begin{tabular}{|c|c|}
\hline Item & $\%$ of dietary DM \\
\hline \multicolumn{2}{|l|}{ Ingredient composition } \\
\hline High-moisture corn & 66.0 \\
\hline Dry-rolled corn & 16.5 \\
\hline Alfalfa hay & 7.5 \\
\hline Molasses & 5.0 \\
\hline Dry, meal supplement ${ }^{1}$ & 5.0 \\
\hline Fine ground corn $^{2}$ & Variable \\
\hline Urea & 1.25 \\
\hline Limestone & 1.53 \\
\hline Salt & 0.30 \\
\hline Potassium chloride & 0.23 \\
\hline Molasses, liquid ${ }^{3}$ & 0.13 \\
\hline Trace mineral premix ${ }^{4}$ & 0.050 \\
\hline Vitamin premix $^{5}$ & 0.015 \\
\hline Essential oil mixture $^{6}$ & 0 or 0.009 \\
\hline Monensin premix ${ }^{7}$ & 0 or 0.016 \\
\hline \multicolumn{2}{|l|}{ Nutrient composition ${ }^{8}$} \\
\hline $\mathrm{CP}$ & 12.7 \\
\hline Calcium & 0.75 \\
\hline Phosphorus & 0.33 \\
\hline Potassium & 0.71 \\
\hline
\end{tabular}

${ }^{1}$ Supplement fed at $5 \%$ of diet DM with fine ground corn as a carrier and dietary treatments included within the supplement. All supplement ingredients are listed as \% of diet DM.

${ }^{2}$ Variable inclusion indicates that feed additives replaced part of fine ground corn.

${ }^{3}$ Molasses included in the supplement as a surfactant and dust controlling agent.

${ }^{4}$ Premix contained $6 \% \mathrm{Zn}, 5 \% \mathrm{Fe}, 4 \% \mathrm{Mn}, 2 \% \mathrm{Cu}, 0.2 \% \mathrm{I}, 0.05 \%$ Co.

${ }^{5}$ Premix contained $32,411 \mathrm{IU}$ of vitamin A, 6,482 IU of vitamin D, $8.1 \mathrm{IU}$ of vitamin E per gram.

${ }^{6}$ Essential oil mixture (DSM Nutritional Products Inc., Parsippany, NJ) formulated to provide 0 or $90 \mathrm{mg} / \mathrm{kg}$ and 0 or $1.0 \mathrm{~g} / \mathrm{steer}$ daily.

${ }^{7}$ Formulated to provide monensin (Elanco Animal Health, Indianapolis, IN) at 0 or $28.2 \mathrm{mg} / \mathrm{kg}$ of DM and 0 or $300 \mathrm{mg} / \mathrm{steer}$ daily.

${ }^{8}$ Based on tabular values for individual feed ingredients (NRC, 1984).

were dosed intraruminally with $7.5 \mathrm{~g}$ of $\mathrm{Cr}_{2} \mathrm{O}_{3}$ twice daily at 0730 and $1930 \mathrm{~h}$ beginning on d 20 of each period and continuing until d 28. Fecal grab samples were collected 3 times daily (d 24 to 28 ) at 0,6 , and 12 $\mathrm{h}$ after feeding. Daily fecal samples were sub-sampled, composited by wet weight, and frozen $\left(-20^{\circ} \mathrm{C}\right)$. On $\mathrm{d}$ 28 , rumen samples were collected at $0,3,6,9,12,18$, and $24 \mathrm{~h}$ after feeding and frozen immediately $\left(-20^{\circ} \mathrm{C}\right)$ for determination of VFA concentrations.

Sample Analysis and Calculations. Diet ingredient samples and feed refusals were dried in a forced air oven $\left(60^{\circ} \mathrm{C}\right.$ for $\left.48 \mathrm{~h}\right)$ and ground to pass through a 1-mm screen (No. 3 Wiley mill, Arthur Thomas Co., Philadelphia, PA). Organic matter of diet ingredient samples and feed refusals was determined by ashing samples at $600^{\circ} \mathrm{C}$ for $6 \mathrm{~h}$ (AOAC, 1995). Ether extract and $\mathrm{CP}$ were analyzed similarly to Exp. 1. Composited fecal samples were freeze-dried (Freezemobile 25SL or 25ES, Virtis Co., Gardiner, NY), ground, composited by period, and analyzed for $\mathrm{Cr}_{2} \mathrm{O}_{3}$ concentrations using an atomic absorption spectrophotometer (SpectrAA-30, Varian Inc., Palo Alto, CA) with an air-acetylene flame according to Williams et al. (1962). Rumen samples were thawed $\left(3^{\circ} \mathrm{C}\right.$ for $\left.24 \mathrm{~h}\right)$ and analyzed for VFA concentration using a gas chromatograph (HP5890 Series II, Hewlett-Packard Co., Palo Alto, CA) according to Erwin et al. (1961).

Statistical Analysis. Data were analyzed using the MIXED procedures of SAS as a replicated $4 \times 4$ Latin square, with animal as the experimental unit. Intake, ruminal $\mathrm{pH}$, and VFA were analyzed as repeated measures using an autoregressive $[\mathrm{AR}(1)]$ covariance structure with day being the repeated measure for intake and ruminal $\mathrm{pH}$ and hour repeated for VFA. For digestibility (DM and $\mathrm{OM}$ ), the model included period and dietary treatment. For intake and ruminal $\mathrm{pH}$ analyses, the model consisted of period, dietary treatment, day of collection period, and their interactions. For VFA analysis the model consisted of period, dietary treatment, time of collection, and their interactions. All models included steer and steer $\times$ dietary treatment $\times$ period as random effects. When treatment differences were significant based on the $F$-test, means were separated using the LSD multiple comparison test. Treatment effects were declared significant at $P \leq 0.10$.

\section{RESULTS AND DISCUSSION}

\section{Exp. 1}

Steers fed CON, EOM, EXP, and EOM+T dietary treatments had greater DMI than steers fed MON+T $(P<0.01$; Table 3$)$. A reduction in DMI with improved G:F is typically observed when cattle are fed monensin plus tylosin (Potter et al., 1985) and is similar to that observed by Stock et al. (1995), who observed a 5.0\% reduction in DMI when individually fed steers received a diet supplemented with $27 \mathrm{mg} / \mathrm{kg}$ of monensin. There were no differences in DMI between CON and treatments with essential oils $(P>0.19)$. Similarly, Chaves et al. (2008) evaluated carvacrol and cinnamaldehyde in lambs fed barley- or corn-based diets and did not observe a DMI response compared with controls.

The EOM+T and MON+T had improved G:F compared with CON $(P<0.01)$. Improved $\mathrm{G}: \mathrm{F}$ in the $\mathrm{EOM}+\mathrm{T}$ may be partially attributable to tylosin. Addition of tylosin has resulted in improvements of ADG by $2.3 \%$ and $\mathrm{F}: \mathrm{G}$ by $2.6 \%(P<0.01)$ with no effect on DMI (Vogel and Laudert, 1994). A tendency $(P \leq$ $0.10)$ for improved G:F was observed in EOM (4.1\%) and EXP (4.1\%) treatments compared with CON, and this was due primarily to numerically greater ADG in these treatments.

Hot carcass weight was unaffected by treatment with a range of 384 to $389 \mathrm{~kg}$. There was a trend $(P=$ 0.09 ) for a treatment effect on 12th-rib fat thickness with $\mathrm{EOM}+\mathrm{T}$ having greater fat thickness compared with MON+T. Longissimus muscle area $(P=0.56)$ and $\mathrm{KPH}(P=0.22)$ were not affected by dietary treatment. 
Table 3. Performance and carcass characteristics of steers fed differing feed additives for a 115-d finishing period (Exp. 1)

\begin{tabular}{|c|c|c|c|c|c|c|c|}
\hline \multirow[b]{2}{*}{ Item } & \multicolumn{5}{|c|}{ Treatment $^{1}$} & \multirow[b]{2}{*}{ SEM } & \multirow[b]{2}{*}{$P$-value } \\
\hline & $\mathrm{CON}$ & $\mathrm{EOM}$ & EXP & $\mathrm{EOM}+\mathrm{T}$ & $\mathrm{MON}+\mathrm{T}$ & & \\
\hline \multicolumn{8}{|l|}{ Performance } \\
\hline Initial BW, kg & 408 & 406 & 407 & 407 & 407 & 0.72 & 0.46 \\
\hline Final calculated $\mathrm{BW},{ }^{2} \mathrm{~kg}$ & 610 & 615 & 615 & 617 & 611 & 3.7 & 0.61 \\
\hline Final BW, kg & 616 & 620 & 620 & 624 & 617 & 3.4 & 0.37 \\
\hline DMI, kg/d & $12.1^{\mathrm{a}}$ & $12.0^{\mathrm{a}}$ & $12.0^{\mathrm{a}}$ & $11.9^{\mathrm{a}}$ & $11.4^{\mathrm{b}}$ & 0.11 & $<0.01$ \\
\hline $\mathrm{ADG},{ }^{2} \mathrm{~kg}$ & 1.76 & 1.81 & 1.81 & 1.83 & 1.78 & 0.033 & 0.59 \\
\hline $\mathrm{G}: \mathrm{F}^{3}$ & $0.145^{\mathrm{a}}$ & $0.151^{\mathrm{ab}}$ & $0.151^{\mathrm{ab}}$ & $0.153^{\mathrm{b}}$ & $0.156^{\mathrm{b}}$ & 0.0024 & 0.05 \\
\hline \multicolumn{8}{|l|}{ Carcass characteristic } \\
\hline $\mathrm{HCW}, \mathrm{kg}$ & 384 & 387 & 388 & 389 & 385 & 2.3 & 0.61 \\
\hline Dressing percent & 62.4 & 62.5 & 62.4 & 62.2 & 62.4 & 0.33 & 0.96 \\
\hline Fat thickness, cm & 1.12 & 1.14 & 1.12 & 1.22 & 1.07 & 0.039 & 0.09 \\
\hline $\mathrm{KPH}, \%$ & 2.07 & 2.00 & 2.05 & 2.00 & 2.01 & 0.027 & 0.22 \\
\hline LM area, $\mathrm{cm}^{2}$ & 91.0 & 91.0 & 91.6 & 89.7 & 91.0 & 0.62 & 0.56 \\
\hline Marbling score ${ }^{4}$ & 553 & 533 & 534 & 554 & 537 & 7.3 & 0.10 \\
\hline Yield grade & $2.1^{\mathrm{a}}$ & $2.3^{\mathrm{a}}$ & $2.3^{\mathrm{a}}$ & $2.7^{\mathrm{b}}$ & $2.3^{\mathrm{a}}$ & 0.14 & 0.04 \\
\hline
\end{tabular}

${ }^{\mathrm{a}, \mathrm{b}}$ Within a row, means without a common superscript letter differ $(P<0.05)$.

${ }^{1} \mathrm{CON}=$ control; EOM $=$ essential oil mixture (DSM Nutritional Products, Parsippany, NJ); EXP $=$ experimental essential oil mixture; EOM+T = EOM+tylosin (Elanco Animal Health, Indianapolis, IN); MON+T = monensin (Elanco Animal Health)+tylosin.

${ }^{2}$ Calculated from carcass weight adjusted to a $63 \%$ common dressing percentage.

${ }^{3}$ Calculated as total BW gain divided by total feed intake (DM basis).

${ }^{4} 400=$ Slight $^{0}, 500=$ Small $^{0}, 550=$ Small $^{50}$.

Marbling score tended to be affected by treatment $(P=$ 0.10 ) with $\mathrm{CON}$ and $\mathrm{EOM}+\mathrm{T}$ having greater marbling scores compared with other treatments. The EOM+T treatment had a greater calculated USDA YG compared with other treatments $(P<0.05)$. It is not clear why the EOM+T treatment had greater 12th-rib fat thickness measure and numerically smaller LM area, resulting in a greater calculated YG compared with all other treatments. No other research is available to compare feedlot cattle performance when fed these essential oils. Bampidis et al. (2005) evaluated performance and carcass characteristics of growing lambs fed dried oregano leaves. The primary essential oils in oregano are carvacrol and thymol with carvacrol being the most abundant. No differences in lamb performance or carcass characteristics were noted when dried oregano leaves were fed at levels of 0,144 , or $288 \mathrm{mg} / \mathrm{kg}$ of a concentrate mixture.

Total liver abscess prevalence ranged from 6.5 to $27.2 \%$ with severe $(\mathrm{A}+)$ liver abscess prevalence ranging from 0 to $9.2 \%$ (Table 4). Essential oil treatments had varying effects on liver abscesses. Compared with CON $(27.2 \%)$, total liver abscesses tended to be reduced $(P=0.08)$ by $39 \%$ in the EOM $(16.6 \%)$ treatment but were not affected $(P=0.92)$ by $\operatorname{EXP}(26.6 \%)$ treatment. Essential oils have been documented as having varying antimicrobial properties (Hammer et al., 1999). Primary etiologic agents identified in liver abscess formation are Fusobacterium necrophorum and Arcanobacterium pyogenes (Nagaraja and Lechtenberg, 2007). Research documenting the bactericidal activity of essential oils on the primary etiological agents in liver abscesses is limited. Prevalences of total liver abscesses in CON were 68 and $76 \%$ greater compared with $\mathrm{EOM}+\mathrm{T}$ and $\mathrm{MON}+\mathrm{T}$, respectively $(P<0.01)$. Reduction in severe liver abscesses appears to be the main factor in performance and carcass response to tylosin (Brink et al., 1990; Davis et al., 2007). Severe liver abscesses in essential oil mixture treatments without tylosin were similar to $\mathrm{CON}(P>0.56)$. Monensin plus tylosin reduced severe liver abscesses compared with CON, EOM, and EXP treatments $(P \leq 0.05)$. The EOM plus tylosin treatment tended $(P=0.10)$ to reduce severe liver abscesses compared with CON (2.9 vs. $8.9 \%)$.

\section{Exp. 2}

Steers had less DMI (7.7 to $9.8 \mathrm{~kg} / \mathrm{d}$; Table 5 ) than predicted $(10.4 \mathrm{~kg} / \mathrm{d})$; thus actual intakes of feed additives were less than the targeted rate. Two steers were removed during 2 different periods due to reduced DMI (criterion was daily DMI $<2.0 \mathrm{~kg}$ ); the 2 treatments that were affected were the EOM and MON. The rumen $\mathrm{pH}$ and DMI data indicated that the steers with reduced intakes were experiencing ruminal acidosis (data not shown). Steers fed EOM and EXP consumed 0.88 and $0.79 \mathrm{~g} / \mathrm{d}$ (predicted was $1.0 \mathrm{~g} / \mathrm{d}$ ). Steers fed MON consumed $217 \mathrm{mg} / \mathrm{d}$. No differences in DMI or OMI were detected $(P>0.20)$ among treatments.

Dry matter digestibilities of the diets were 82.8, 85.1, 85.1 , and $84.0 \%$ for CON, EOM, EXP, and MON, respectively. There were no significant differences $(P>$ $0.20)$ in $\mathrm{DM}$ or $\mathrm{OM}$ digestibility due to inclusion of feed additive. Although steers fed the EOM treatment consumed $1.2 \mathrm{~kg}$ more and had a 2.3 percentage unit 
Table 4. Liver abscess prevalence of steers fed differing feed additives (Exp. 1) ${ }^{1}$

\begin{tabular}{|c|c|c|c|c|c|c|c|}
\hline \multirow[b]{2}{*}{ Item } & \multicolumn{5}{|c|}{ Treatment $^{2}$} & \multirow[b]{2}{*}{ SEM } & \multirow[b]{2}{*}{$P$-value } \\
\hline & $\mathrm{CON}$ & EOM & EXP & $\mathrm{EOM}+\mathrm{T}$ & $\mathrm{MON}+\mathrm{T}$ & & \\
\hline Steers, n & 93 & 94 & 93 & 93 & 92 & & \\
\hline $\mathrm{A}+, \mathrm{n}$ & 9 & 7 & 9 & 3 & 0 & & \\
\hline $\mathrm{A}, \mathrm{n}$ & 2 & 0 & 3 & 0 & 0 & & \\
\hline $\mathrm{A}-, \mathrm{n}$ & 15 & 9 & 13 & 5 & 6 & & \\
\hline $\mathrm{A}+{ }^{3} \%$ & $8.9^{\mathrm{a}}$ & $6.9^{\mathrm{a}}$ & $9.2^{\mathrm{a}}$ & $2.9^{\mathrm{ab}}$ & $0.0^{\mathrm{b}}$ & 2.6 & 0.04 \\
\hline Total abscesses, ${ }^{3} \%$ & $27.2^{\mathrm{a}}$ & $16.6^{\mathrm{ab}}$ & $26.6^{\mathrm{a}}$ & $8.6^{\mathrm{bc}}$ & $6.5^{\mathrm{c}}$ & 4.3 & $<0.01$ \\
\hline
\end{tabular}

greater DM digestibility compared with $\mathrm{CON}$, this was not significant. Benchaar et al. (2006a) observed an increase in DMI when steers were fed a differing essential oil mixture (Vertran, IDENA, Sautron, France), but similar to our results, they did not observe a difference in DM digestibility compared with a control diet. Average number of meals per day were $6.4,5.5,6.0$, and 5.7 for CON, EOM, EXP, and MON, respectively $(P=$ $0.29)$. No differences were observed for total time eating or meal size $(P>0.20)$. Steers fed feed additives had a greater meal length compared with $\mathrm{CON}(P \leq$ 0.08). Alternatively, Erickson et al. (2003) observed a decrease in meal length when monensin was fed $(P=$ $0.10)$ during a prechallenge phase and no effect $(P=$ 0.81 ) on meal length during a challenge phase when steers were fed $4 \mathrm{~h}$ late and received $125 \%$ of the DMI of the previous day.

Ruminal pH (Table 6) averaged 5.64 across treatments and was not different among treatments $(P=$
$0.55)$. The treatments did not affect $\mathrm{pH}$ change or $\mathrm{pH}$ variance $(P=0.73)$. Time spent with a $\mathrm{pH}$ below 5.0 was less for EOM compared with $\mathrm{MON}(P=0.10)$, but this did not translate into less area of the curve below $\mathrm{pH} 5.0$, which takes into account the magnitude and time below pH 5.0 (Cooper et al., 1999). Benchaar et al. (2006b, 2007) showed a slight increase in $\mathrm{pH}$, whereas Newbold et al. (2004), Beauchemin and McGinn (2006), and Castillejos et al. (2007) were unable to detect any differences in rumen $\mathrm{pH}$ when essential oil mixtures were administered. These differing results may be partially explained by the type of diets and species utilized with slightly greater $\mathrm{pH}$ values being reported when the essential oil mixture was supplemented in greater forage, dairy-type diets.

Total VFA concentrations were affected by treatment $(P=0.10)$, which was $15 \%$ greater in steers fed EOM compared with CON $(P=0.07)$ and $20 \%$ greater compared with MON $(P=0.03)$. Total VFA concentrations

Table 5. Effects of feed additives on nutrient digestibility and feed intake (Exp. 2)

\begin{tabular}{|c|c|c|c|c|c|c|}
\hline \multirow[b]{2}{*}{ Item } & \multicolumn{4}{|c|}{ Treatment $^{1}$} & \multirow[b]{2}{*}{$\mathrm{SEM}^{2}$} & \multirow[b]{2}{*}{$P$-value } \\
\hline & $\mathrm{CON}$ & EOM & EXP & MON & & \\
\hline \multicolumn{7}{|c|}{ Intake and digestibility } \\
\hline Observations, $\mathrm{n}$ & 7 & 6 & 8 & 6 & & \\
\hline \multicolumn{7}{|l|}{ DM } \\
\hline Intake, kg/d & 8.6 & 9.8 & 8.8 & 7.7 & 1.1 & 0.33 \\
\hline Digestibility, \% & 82.8 & 85.1 & 85.1 & 84.0 & 1.7 & 0.62 \\
\hline \multicolumn{7}{|l|}{$\mathrm{OM}$} \\
\hline Intake, $\mathrm{kg} / \mathrm{d}$ & 8.3 & 9.4 & 8.3 & 7.4 & 1.0 & 0.31 \\
\hline Digestibility, \% & 84.5 & 86.8 & 86.7 & 85.6 & 1.6 & 0.62 \\
\hline \multicolumn{7}{|l|}{ Intake patterns } \\
\hline Observations, $\mathrm{n}$ & 37 & 29 & 38 & 32 & & \\
\hline Meals, ${ }^{3}$ number/d & 6.4 & 5.5 & 6.0 & 5.7 & 0.75 & 0.29 \\
\hline Time eating, min & 369 & 373 & 390 & 374 & 51 & 0.93 \\
\hline Meal size ${ }^{3} \mathrm{~kg}$ & 1.6 & 2.0 & 1.8 & 1.5 & 0.18 & 0.25 \\
\hline Meal length, min & 60 & 70 & 70 & 69 & 3.9 & 0.14 \\
\hline
\end{tabular}

${ }^{1} \mathrm{CON}=$ control; $\mathrm{EOM}=$ essential oil mixture (DSM Nutritional Products, Parsippany, NJ); EXP $=$ experimental essential oil mixture; MON = monensin (Elanco Animal Health, Indianapolis, IN).

${ }^{2} \mathrm{SEM}=$ largest SEM among treatment means.

${ }^{3}$ Meal is defined as an eating bout where $\geq 0.45 \mathrm{~kg}$ of feed is consumed. 
Table 6. Effects of feed additives on rumen fermentation characteristics (Exp. 2)

\begin{tabular}{|c|c|c|c|c|c|c|}
\hline \multirow[b]{2}{*}{ Item } & \multicolumn{4}{|c|}{ Treatment $^{1}$} & \multirow[b]{2}{*}{$\mathrm{SEM}^{2}$} & \multirow[b]{2}{*}{$P$-value } \\
\hline & $\mathrm{CON}$ & EOM & EXP & MON & & \\
\hline Observations, $\mathrm{n}$ & 35 & 27 & 38 & 32 & & \\
\hline \multicolumn{7}{|l|}{ Rumen pH } \\
\hline Average $\mathrm{pH}$ & 5.72 & 5.64 & 5.60 & 5.59 & 0.080 & 0.55 \\
\hline $\mathrm{pH}$ change & 1.55 & 1.76 & 1.48 & 1.51 & 0.20 & 0.73 \\
\hline $\mathrm{pH}$ variance & 0.120 & 0.140 & 0.123 & 0.118 & 0.021 & 0.85 \\
\hline Time $<5.3, \min$ & 362 & 305 & 487 & 463 & 85 & 0.32 \\
\hline Area $<5.3$ & 67 & 50 & 88 & 107 & 30 & 0.50 \\
\hline Time $<5.0$, min & $64^{\mathrm{ab}}$ & $5^{\mathrm{a}}$ & $72^{\mathrm{ab}}$ & $124^{\mathrm{b}}$ & 64 & 0.10 \\
\hline Area $<5.0$ & 10 & 19 & 3 & 17 & 15 & 0.81 \\
\hline Observations, n & 56 & 42 & 56 & 49 & & \\
\hline \multicolumn{7}{|l|}{ VFA concentration ${ }^{3}$} \\
\hline Total, $\mathrm{m} M$ & $109.2^{\mathrm{ab}}$ & $125.2^{\mathrm{c}}$ & $118.7^{\mathrm{bc}}$ & $104.7^{\mathrm{a}}$ & 7.8 & 0.10 \\
\hline Acetate, $\mathrm{m} M$ & $54.4^{\mathrm{ad}}$ & $63.4^{\mathrm{bc}}$ & $59.1^{\text {ac }}$ & $51.9^{\mathrm{d}}$ & 3.4 & 0.06 \\
\hline Propionate, $\mathrm{m} M$ & 32.9 & 42.5 & 39.6 & 35.5 & 5.8 & 0.41 \\
\hline Butyrate, $\mathrm{m} M$ & 13.6 & 12.2 & 13.4 & 11.2 & 2.3 & 0.78 \\
\hline Acetate:propionate & 2.24 & 1.60 & 1.80 & 1.75 & 0.37 & 0.21 \\
\hline \multicolumn{7}{|l|}{ VFA proportion } \\
\hline Acetate, mol/100 mol & 50.9 & 50.6 & 50.3 & 50.1 & 2.4 & 0.99 \\
\hline Propionate, $\mathrm{mol} / 100 \mathrm{~mol}$ & 28.5 & 33.8 & 32.3 & 32.8 & 3.8 & 0.43 \\
\hline Butyrate, mol/100 mol & 12.9 & 9.9 & 11.2 & 11.2 & 2.1 & 0.71 \\
\hline
\end{tabular}

have been reported as lesser (Varga et al., 2004), greater (Castillejos et al., 2005), and mixed or not different (Newbold et al., 2004; Benchaar et al., 2007; Castillejos et al., 2007) when EOM was tested. Many studies evaluating essential oil mixtures have been conducted utilizing both in vitro and in vivo systems with diets containing greater dietary proportions of forage than what was utilized in our study. These data should be looked at discerningly in the context of this study because many of the effects of plant extracts on ruminal fermentation interact with $\mathrm{pH}$ (Cardozo et al., 2005). Contrary to Cardozo et al. (2005), Castillejos et al. (2005) did not observe a type of diet $\times$ EOM interaction on ruminal fermentation characteristics. Monensin treatment has resulted in no effect on total VFA and increased concentrations of propionate (Richardson et al., 1976). Acetate concentrations were affected by dietary treatment $(P=0.06)$, with greater acetate for EOM compared with CON $(P=0.04)$ and $\mathrm{MON}(P=$ $0.01)$. Propionate $(P=0.41)$ and buyrate $(P=0.78)$ concentrations were unaffected by dietary treatment. Compared with CON, the EOM treatment tended to have an increased concentration of acetate with numerical increases in propionate and a subsequent numerically decreased acetate:propionate ratio. Others have observed similar responses (Castillejos et al., 2005), and it has been suggested that responses to essential oil mixtures indicate a differing mode of action compared with monensin. Although DMI was not significantly different among treatments, the large variation in DMI does make the ruminal $\mathrm{pH}$ and VFA data difficult to interpret and may have influenced VFA concentrations. Interestingly, when analyzing the VFA data on a molar proportion basis, which is probably the best measure of impact on ruminal fermentation, there were no treatment effects on acetate, propionate, or butyrate proportions $(P>0.42)$. The molar proportion of acetate was identical across treatments, whereas molar proportion of propionate was numerically greater for all 3 additive treatments, but was not significant. Similar to propionate, a numeric $(P=0.21)$ decrease that is likely biologically significant (2.2 to 1.6 ) was observed in acetate:propionate ratio for all dietary additives, but we cannot conclude these are different in this study. A typical response to monensin is a decrease or no change in acetate concentration with greater propionate concentration resulting in a reduced acetate:propionate ratio (Yang and Russell, 1993). Based on our data, it is reasonable to conclude that EOM and EXP had little impact on ruminal fermentation.

A mechanistic explanation on how essential oil mixtures affect ruminal fermentation through microorganism modification has not been clearly established. Evans and Martin (2000) examined the effects of thymol on ruminal microorganisms. Thymol, which is a constituent of the EOM tested, inhibited gram-positive bacteria (Streptococcus bovis JB1) at $180 \mu \mathrm{g}$ of thymol $/ \mathrm{mL}$ and gram-negative bacteria (Selenomonas ruminantium $\mathrm{HD} 4)$ at $90 \mu \mathrm{g}$ of thymol $/ \mathrm{mL}$. Although these in vitro concentrations are much greater than the theoretical expected concentration of the mixtures tested in our experiment, bacterial inhibition would be a potential 
cause of altered fermentation patterns. It does not appear that EOM has an effect on specific bacterial colonization of starch-rich substrates in the rumen (Duval et al., 2007). McIntosh et al. (2003) determined that activity of ruminal protozoa was unaffected by EOM treatment. Other researchers have observed no response in protozoal populations when EOM was administered (Newbold et al., 2004; Benchaar et al., 2006b, 2007).

Essential oil mixture treatments were at least equivalent to a diet not supplemented with additives. Additionally, the inclusion of an essential oil mixture plus tylosin resulted in similar performance, carcass, and liver abscesses compared with monensin plus tylosin. Minimal digestibility, intake pattern, ruminal $\mathrm{pH}$, and ruminal VFA differences were observed, but trends indicated that the mode of action of essential oils may differ compared with monensin. Responses to feed additive compounds are dependent on the type and dose of additive used. Further efforts should focus on defining specific types and doses of essential oils that result in the most favorable responses.

\section{LITERATURE CITED}

AOAC. 1995. Official Methods of Analysis. 14th ed. Assoc. Off. Anal. Chem., Arlington, VA.

Bampidis, V. A., V. Christodoulou, P. Florou-Paneri, E. Christaki, A. B. Spais, and P. S. Chatzopoulou. 2005. Effect of dietary dried oregano leaves supplementation on performance and carcass characteristics of growing lambs. Anim. Feed Sci. Technol. 121:285-295.

Beauchemin, K. A., and S. M. McGinn. 2006. Methane emissions from beef cattle: Effects of fumaric acid, essential oil, and canola oil. J. Anim. Sci. 84:1489-1496.

Benchaar, C., S. Calsamiglia, A. V. Chaves, G. R. Fraser, D. Colombatto, T. A. McAllister, and K. A. Beauchemin. 2008. A review of plant-derived essential oils in ruminant nutrition and production. Anim. Feed Sci. Technol. 145:209-228.

Benchaar, C., J. L. Duynisveld, and E. Charmley. 2006a. Effects of monensin and increasing dose levels of a mixture of essential oil compounds on intake, digestion and growth performance of beef cattle. Can. J. Anim. Sci. 86:91-96.

Benchaar, C., H. V. Petit, R. Berthiaume, D. R. Ouellet, J. Chiquette, and P. Y. Chouinard. 2007. Effects of essential oils on digestion, ruminal fermentation, rumen microbial populations, milk production, and milk composition in dairy cows fed alfalfa silage or corn silage. J. Dairy Sci. 90:886-897.

Benchaar, C., H. V. Petit, R. Berthiaume, T. D. Whyte, and P. Y. Chouinard. 2006b. Effects of addition of essential oils and monensin premix on digestion, ruminal fermentation, milk production, and milk composition in dairy cows. J. Dairy Sci. 89:4352-4364.

Boggs, D. L., and R. A. Merkel. 1993. Beef carcass evaluation, grading, and pricing. Pages 105-130 in Live Animal Carcass Evaluation and Selection Manual. D. L. Boggs and R. A. Merkel, ed. Kendall/Hunt Publishing Co., Dubuque, IA.

Brink, D. R., S. R. Lowry, R. A. Stock, and J. C. Parrott. 1990. Severity of liver abscesses and efficiency of feed utilization of feedlot cattle. J. Anim. Sci. 68:1201-1207.

Calsamiglia, S., M. Busquet, P. W. Cardozo, L. Castillejos, and A. Ferret. 2007. Essential oils as modifiers of rumen microbial fermentation. J. Dairy Sci. 90:2580-2595.

Cardozo, P. W., S. Calsamiglia, A. Ferret, and C. Kamel. 2005. Screening for the effects of natural plant extracts at different
$\mathrm{pH}$ on in vitro rumen microbial fermentation of a high-concentrate diet for beef cattle. J. Anim. Sci. 83:2572-2579.

Castillejos, L., S. Calsamiglia, A. Ferret, and R. Losa. 2005. Effects of a specific blend of essential oil compounds and the type of diet on rumen microbial fermentation and nutrient flow from a continuous culture system. Anim. Feed Sci. Technol. 119:29-41.

Castillejos, L., S. Calsamiglia, A. Ferret, and R. Losa. 2007. Effects of dose and adaptation time of a specific blend of essential oil compounds on rumen fermentation. Anim. Feed Sci. Technol. 132:186-201.

Chaves, A. V., K. Stanford, L. L. Gibson, T. A. McAllister, and C. Benchaar. 2008. Effects of carvacrol and cinnamaldehyde on intake, rumen fermentation, growth performance, and carcass characteristics of growing lambs. Anim. Feed Sci. Technol. 145:396-408.

Cooper, R. J., T. J. Klopfenstein, R. A. Stock, C. T. Milton, D. W. Herold, and J. C. Parrott. 1999. Effects of imposed feed intake variation on acidosis and performance of finishing steers. J. Anim. Sci. 77:1093-1099.

Davis, M. S., W. C. Koers, K. J. Vander Pol, and O. A. Turgeon Jr. 2007. Liver abscess score and carcass characteristics of feedlot cattle. J. Anim. Sci. 85(Suppl. 2):126.

Duval, S. M., N. R. McEwan, R. C. Graham, R. J. Wallace, and C. J. Newbold. 2007. Effect of a blend of essential oil compounds on the colonization of starch-rich substrates by bacteria in the rumen. J. Appl. Microbiol. 103:2132-2141.

Erickson, G. E., C. T. Milton, K. C. Fanning, R. J. Cooper, R. S. Swingle, J. C. Parrott, G. Vogel, and T. J. Klopfenstein. 2003. Interaction between bunk management and monensin concentration on finishing performance, feeding behavior, and ruminal metabolism during an acidosis challenge with feedlot cattle. J. Anim. Sci. 81:2869-2879.

Erwin, E. S., G. J. Marco, and E. M. Emery. 1961. Volatile fatty acid analyses of blood and rumen fluid by gas chromatography. J. Dairy Sci. 44:1768-1771.

Evans, J. D., and S. A. Martin. 2000. Effects of thymol on ruminal microorganisms. Curr. Microbiol. 41:336-340.

Hammer, K. A., C. F. Carson, and T. V. Riley. 1999. Antimicrobial activity of essential oils and other plant extracts. J. Appl. Microbiol. 86:985-990.

McIntosh, F. M., P. Williams, R. Losa, R. J. Wallace, D. A. Beever, and C. J. Newbold. 2003. Effects of essential oils on ruminal microorganisms and their protein metabolism. Appl. Environ. Microbiol. 69:5011-5014.

Nagaraja, T. G., and K. F. Lechtenberg. 2007. Liver abscesses in feedlot cattle. Vet. Clin. North Am. Food Anim. Pract. 23:351-369.

Newbold, C. J., F. M. McIntosh, P. Williams, R. Losa, and R. J. Wallace. 2004. Effects of a specific blend of essential oil compounds on rumen fermentation. Anim. Feed Sci. Technol. 114:105-112.

NRC. 1984. Nutrient Requirements of Beef Cattle. 6th rev. ed. Natl. Acad. Press, Washington, DC.

NRC. 1996. Nutrient Requirements of Beef Cattle. 7th rev. ed. Natl. Acad. Press, Washington, DC.

Potter, E. L., M. I. Wray, R. D. Muller, H. P. Grueter, J. McAskill, and D. C. Young. 1985. Effect of monensin and tylosin on average daily gain, feed efficiency and liver abscess incidence in feedlot cattle. J. Anim. Sci. 61:1058-1065.

Richardson, L. F., A. P. Raun, E. L. Potter, C. O. Cooley, and R. P. Rathmacher. 1976. Effect of monensin on rumen fermentation in vitro and in vivo. J. Anim. Sci. 43:657-664.

Stock, R., T. Klopfenstein, D. Brink, S. Lowry, D. Rock, and S. Abrams. 1983. Impact of weighing procedures and variation in protein degradation rate on measured performance of growing lambs and cattle. J. Anim. Sci. 57:1276-1285.

Stock, R. A., S. B. Laudert, W. W. Stroup, E. M. Larson, J. C. Parrott, and R. A. Britton. 1995. Effects of monensin and mon- 
ensin and tylosin combinations on feed intake variation of feedlot steers. J. Anim. Sci. 73:39-44.

Stock, R. A., M. H. Sindt, R. M. Cleale 4th, and R. A. Britton. 1991. High-moisture corn utilization in finishing cattle. J. Anim. Sci. 69:1645-1656.

Varga, G., E. Block, P. Williams, T. W. Cassidy, and R. Losa. 2004. Effect of crina ruminants, a mixture of essential oil components, on continuous culture fermentation and milk production of lactating cows. J. Anim. Sci. 82(Suppl. 1):334.

Vogel, G. J., and S. B. Laudert. 1994. The influence of tylan on liver abscess control and animal performance-A 40 trial summary. J. Anim. Sci. 72(Suppl. 1):293.
Williams, C. H., D. J. David, and O. Iismaa. 1962. The determination of chromic oxide in faeces samples by atomic absorption spectrophotometry. J. Agric. Sci. Camb. 59:381-385.

Yang, C. M., and J. B. Russell. 1993. The effect of monensin supplementation on ruminal ammonia accumulation in-vivo and the numbers of amino acid-fermenting bacteria. J. Anim. Sci. 71:3470-3476. 